\title{
Socioeconomic Determinants of Tree Planting on Farmers Landholding, in Womberma District, Northwestern Ethiopia
}

\author{
Alebel Melaku* \\ Department of natural resources management, Debre Markos University \\ PO box 269, Debre Markos, Ethiopia \\ Zebene Asfaw \\ Wondo Genet College of Forestry and Natural Resources, Hawassa University. \\ P.O. Box, 128, Shashemane, Ethiopia
}

\begin{abstract}
The study was conducted at Womberma district, northwestern Ethiopia with intended to identify the socioeconomic determinants of tree integration on farmer's landholding. Farm visits and total enumeration of trees species on respondent's landholding in different tree growing niches, household interview, and key informant interview were used for data collection. Data were analyzed with multiple linear regression model. The result shows that all the considered predictor variables jointly influenced the total number of tree integrated on their own lands with a coefficient of determination $\left(\mathrm{R}^{2}, 0.719\right.$ and 0.600 in the two study sites). Among the household characteristics that were entered to the model, landholding size, farming experience and wealth status of the household have been significantly related to the number of trees maintained per household. The number of tree stems and tree species per household increase with increasing wealth statuses of households, farming experience, and landholding size.
\end{abstract}

Keywords: Household, Tree species, Wealth status, Tree integration

DOI: $10.7176 / \mathrm{JESD} / 11-7-04$

Publication date: April $30^{\text {th }} 2020$

\section{Introduction}

The presence and future preservation of the woody species in agricultural landscapes ultimately depend on the farmers who own and manage the land and the principal value of woody species in agricultural landscapes lies in their utility for resource-poor farmers (Gordon, Hawthorne, Sandoval, \& Barrance, 2003). The decision of farmers to maintain tree species on their farmlands is strongly driven by the needs of their land use system. Thus, farmers manage trees on their farmlands in search of their livelihood goals of income generation, risk management, household food security, and optimal use of available land, labor, and capital goods (Arnold \& Dewees, 1998).

However, a host of biological, socioeconomic and policy factors influence farmer management and quantity of tree densities in agricultural landscapes (Boffa, Kindt, Katumba, Jourget, \& Turyomurugyendo, 2008; Zeleke, 2009). For instance, agro-ecological characteristics, tree characteristics, landholding size, access to market, wealth status of households, education status, extension services, and labor requirement are known to be the major influencing factors (Etongo, Djenontin, Kanninen, \& Fobissie, 2015; Gessesse, Bewket, \& Bräuning, 2016; Shete \& Fred, 2010).

Farmers in the study area have accumulated experiences on how to manage and take advantage of their trees on farmlands. This allows them to survive and adjust to unpredictable climatic conditions. However, the socioeconomic determinants of tree integration in this area have not been studied. Therefore, this study aimed to explore the socio-economic conditions in which on-farm trees can benefit the farming community in Womberma district. Thus, it is important to determine what socioeconomic factors are behind integrating trees on the agricultural landscape that determine the number of trees on farmers landholding for future preservation and recommending solutions.

\section{Materials and Methods}

Study area description and sampling

The study was conducted during 2017 in the Womberma district, northwestern Ethiopia. The district has a land of diverse topography with an altitude that ranges from 800 to $2212 \mathrm{~m}$ a.s.1., laying $10^{\circ} 19^{\prime} 0^{\prime \prime} \mathrm{N}$ to $10^{\circ} 44^{\prime} 0^{\prime \prime} \mathrm{N}$ latitude and $36^{\circ} 30^{\prime} 5^{\prime \prime} \mathrm{E}$ to $37^{\circ} 1^{\prime} 0^{\prime \prime}$ longitude. The annual mean temperature for most parts of the district is between 14 and $26^{\circ} \mathrm{C}$ (WDOARD, 2011). Agriculture is the main source of livelihood in the area, where the farming system in the areas is characterized by crop-livestock mixed farming (WDOARD, 2011).

Two kebeles (Dafni-Shambla and Kentefin) (the lower administrative unit next to district) and six villages (Huayta, Warba, Shambla, Mehal Damot, Mehal Bitir and Bitir) from the two kebeles (3 from each) were purposively selected based on the existence of planted and/or retained tree species on farmlands. Then, a total of ninety-four sample households were selected following the stratification of households $\mathrm{HH}$ ) in each village into 
wealth category based on local criteria with the help of key informants. Then, a random selection method was employed to obtain samples of households from each wealth category based on proportional representation (Yamane, 1967). The purpose of categorization is too homogenous population is to analyze the effect of wealth status on the number of trees integrated on farmlands at the household level.

\section{Data collection}

To obtain qualitative and quantitative data, both primary and secondary data were collected. The primary data was collected through farm visits and recording, a household questionnaire survey, key informant interview (selected by snowball sampling technique). Secondary data were collected from annual reports, journals, and books relevant to the area of research. Before conducting the detailed data collection, discussions with the District Office of Agriculture and rural development representatives and field visit was held to notify and create awareness about the objective of the study and to select study kebeles. In this study, a household is defined as a basic unit of production and consumption, made up from the persons who manage common landholdings and live under one central decision maker (household head). Data was collected using both close-ended (such as marital status) and open-ended (such as landholding size, age, farming experience) questionnaires. During the interview, every sample household was visited and household heads were interviewed.

A tree is a self-supporting woody perennial with a single main stem, or in the case of coppice with several stems, having a more or less definite crown (FAO, 2005). For this study, this definition was considered only for those tree species which were taller than $5 \mathrm{~m}$ retained or planted as a woodlot, on the farm and/or home boundary, or on crop fields and homestead yards. Thus, a total enumeration of all tree species was conducted on farms of the selected respondent households.

For woodlot plantations, $10 \%$ of the land size was sampled with $5 \times 10 \mathrm{~m}$ sample plots with some modifications of the approach by (Asfaw, 2003). This study only considered farmer-owned private woodlot plantations in agricultural landscapes. Communal and government plantations are not included in this study. For the inventory of boundary plantations, the total length of boundary plantations was divided into $10 \mathrm{~m}$ sections, one section was selected for every $50 \mathrm{~m}$ of boundary length. When the length is less than $10 \mathrm{~m}$, the actual length was considered (Scherr, Roger, \& Oduol, 1990). Inventory of homestead trees and trees on parkland were inventoried by taking one quadrat sample for each tree planting niche from a household farm based on the approach of (Nikiema, van der Maesen, Hall, \& Baas, 2005). Thus, a quadrat size of $10 \times 5 \mathrm{~m}$ and $50 \times 50 \mathrm{~m}$ was used for homestead trees and parklands, respectively. Farm size was estimated by farmers in their local measurement unit, called "Gezim", which is equivalent to 0.25 ha.

For the identification of the farm area and the local names of tree/shrub species on the farm, the owners of the farm were involved in the counting and identification of species with a local name. For tree species identification, different reference materials, such as (Bekele-tesemma, 2007; Hedberg \& Sue, 1989) were used.

\section{Data analysis}

Multiple linear regression analysis has been done to evaluate the importance of household socioeconomic characteristics in influencing the number of trees farmers to integrate on their farmlands. The explanatory variables included in the analysis were the gender of household head, farming experience, household size, educational status, off-farm work, wealth status and landholding size in hectares of the household. Those all variables were surveyed during the household interview. The dependent variable used in the analysis was the number of trees stems that farmers integrate with their farming land. Collected data was initially coded and enter into the computer. Data were checked randomly against the original completed questionnaires to detect entry errors. Then, the socioeconomic determinants of farmer's tree integration were analyzed by multiple linear regressions employing Statistical Package for Social Sciences (SPSS) Version 20.

\section{Result and discussion}

The computed value suggested that all the considered predictor variables (gender of household head, farming experience, household size, educational status, off-farm work, wealth status and landholding size) jointly influenced the farmers' decisions to plant trees to manage their own lands with coefficient of determination $\left(\mathrm{R}^{2}, 0.719\right.$ in Dafni-shambla and 0.600 in Kentefin kebele), which implies that the socio-economic characteristics of respondent households explained about $71.9 \%$ and $60 \%$ of the variation in the number of trees at household level in Dafni-Shambla and Kentefin kebeles, respectively. Among those, the landholding size of households, farming experience (years), and wealth status have a significant $(\mathrm{p}<0.001)$ relationship with the number of tree stems per respondent households (Table 1). However, the variables have a different relationship with the number of trees in the two kebeles. For instance, wealth status and landholding size of household was significantly related $(\mathrm{p}<0.05$, ) to the number of trees stems in the Dafni-Shambla kebele, while variables such as farming experience $(p<0.001)$ and wealth status of the household $(p<0.1)$ and age of household head $(p<0.05)$ was significant $(p<0.05)$ for determining the number of trees on farmlands at the household level in the Kentefin kebele (Table 1). 


\section{Wealth status}

Wealth status of respondents has a positive and significant relationship with the number of trees at the household level in both study kebeles (Table 1). Rich households had a high chance of planting and retaining trees on their farms. Specifically, the increase of wealth status results in increases in a number of tree planting and retention by a factor of $118.13(\mathrm{p}<0.01)$ in Dafni-Shambla and $29.56(\mathrm{p}<0.1)$. This is due to the fact that wealthy respondents have larger landholding and capital than poor household and poor household focused on annual crops, such as maize, wheat, pepper rather than planting trees on their farm because they want to get their subsistence food than long term investments like growing trees on their farms. This result is in line with (Abiyu \& Gratzer, 2009; Oeba, Otor, Kung, \& Muchiri, 2012) which reveals that farmers with high income and large farm size have greater tendency to plant more trees than farmers with low farm size and farmers poor wealth status. Several studies reported that lack of capital has an influence on the tree density and tree species-preference and other management activities on farmlands (Adal \& Asfaw, 2015; Asfaw, 2003; Cerdán, Rebolledo, Soto, Rapidel, \& Sinclair, 2012; Lemage \& Legesse, 2018; Nair, 1993; Shete \& Fred, 2010).

\section{Farming experience}

The number of years that a household has was positively and significantly $(\mathrm{p}<0.001)$ related to the number of trees stems per household in Kentefin kebele. Farmers who have lived in and farmed longer on their present landholding would have more awareness of farming and information about the benefits from tree integration. The coefficient of the regression (6.63) implies that an increasing number of years that households resided on the present landholding by one year increase the number of trees by a factor of 6.63 (Table 1). This result is in agreement with (Shete \& Fred, 2010), which confirms that farmers with longer farming experience had a lower level of food crop requirements with decreasing family size and due to reduced risks anticipated in tree production. Moreover, older farmers may tend to shift to growing trees as an asset for retirement (Shete \& Fred, 2010).

\section{Landholding size}

Landholding size is often hypothesized as a determinant of tree adoption. Despite the recognition of the value of on-farm trees, this practice will not bring a fundamental change to the positions of the landless and poor households where inequities in landholding exist. Rather these practices provide a higher financial return to land-rich and lower financial return to the land-poor households. Farmers with larger farm size are probably able to plant trees compared to farmers with small farm size who are unable or unwilling to plant trees. Limited land influence agroforestry practice and therefore deserves particular attention when planning and implementing agroforestry development. Similar reports of positive effects of farm size on tree planting were also reported in Tigray, Ethiopia (Gebreegziabher \& Mekonnen, 2010; Mekonnen \& Damte, 2011). Farmers with less access to resources, particularly land, may focus on the cultivation of a few staple food crops for their subsistence production, depending on their individual relative benefit. For case, farmers with small farm size could not cover a large stock of trees since the available land is primarily used for producing crops for subsistence use because tree planting is a long-term investment. Large landholders, on the other hand, could produce a large volume of wood by growing trees on their landholding (Zeleke, 2009). There can also be more fundamental economic pressures that prevent or discourage farmers from managing trees into their agricultural lands (Abiyu \& Gratzer, 2009; Oeba et al., 2012). Farmers with larger farm size are probably able to plant trees compared to farmers with small farm size who are unable or unwilling to plant trees. Limited land influence agroforestry practice and therefore deserves particular attention when planning and implementing agroforestry development. Similar reports of positive effects of farm size on tree planting were also reported in Tigray, Ethiopia (Gebreegziabher \& Mekonnen, 2010).

\section{Age of household head}

The age of head of the household also has negative and statistically significant $(p<0.05)$ in Kentefin kebele. The negative coefficient indicates that an increase of the age of household head by one year results decreasing the number of trees by a factor of $3.5(\mathrm{p}<0.05)$. This may be due to young farmers are often flexible, have higher risk aversion, and less willing to long term investment such as tree planting and the result was supported by (Zeleke, 2009).

The gender of head of household may also influence which trees to grow on farmland, because the head of the household may make different decisions in relation to managing trees. For instance, Women may favor fruit and fodder trees close to homesteads and men may favor woodlots away from the homestead for timber construction materials, etc depending on their use in the household. Results in a study by (Abiyu, Shete, \& Gratzer, 2012) showed that gender had significance influence on the types of indigenous trees retained and a number of trees retained. The author found that male respondents retained or planted more trees species in their farms compared to female respondents.

In general, analysis of household characteristics showed that those households with bigger landholding size, age, and long farming experience grow the higher number of trees than the other ones. In other words, wealthy 
households and farmers with higher farming experience grow and maintain more trees than poor farmers and households with low farming experience. Thus, the study has found evidence supporting the assertion that socioeconomic variables such as landholding size, farming experience, wealth status, age of the household and farming experience are worth considering in determining the number of trees managed at the household level. Our finding also pointed out that, integration of trees at the household level varied depending on the individual household socioeconomic characteristics.

\section{References}

Abiyu, A., \& Gratzer, G. (2009). Native woody plants for livelihood in North Western Ethiopia: drivers of diversity and management constraints Tropentag 2009 University of Hamburg , October 6-8 , 2009. Conference on International Research on Food Security, Natural Resource Management and Rural Development, (October).

Abiyu, A., Shete, M., \& Gratzer, G. (2012). Spatial Patterns and Determinants of Smallholder Tree Planting in Northwest Highlands of Ethiopia Abrham. JAD, 2, 2.

Adal, H. M., \& Asfaw, Z. (2015). Smallholder farmers' perceptions, attitudes, and management of trees in farmed landscapes in northeastern ethiopia.

Arnold, M., \& Dewees, P. (1998). Rethinking approaches to tree management by farmers.

Asfaw, Z. (2003). Tree species diversity, topsoil conditions and arbuscular mycorrhizal association in the Sidama traditional agroforestry land use, southern Ethiopia. Retrieved from http://urn.kb.se/resolve?urn=urn:nbn:se:slu:epsilon-165

Bekele-tesemma, A. (2007). Useful trees and shrubs of Ethiopia : Identification, Propagation and Management for 17 Agroclimatic Zones. Relma in ICRAF Project, 552p.

Boffa, J., Kindt, R., Katumba, B., Jourget, J., \& Turyomurugyendo, L. (2008). Management of tree diversity in agricultural landscapes around Mabira Forest Reserve , Uganda. African Journal of Ecology, 46, $24-32$.

Cerdán, C. R., Rebolledo, M. C., Soto, G., Rapidel, B., \& Sinclair, F. L. (2012). Local knowledge of impacts of tree cover on ecosystem services in smallholder coffee production systems. 110, 119-130. https://doi.org/10.1016/j.agsy.2012.03.014

Etongo, D., Djenontin, I. N. S., Kanninen, M., \& Fobissie, K. (2015). Smallholders' Tree Planting Activity in the Ziro Province, Southern Burkina Faso: Impacts on Livelihood and Policy Implications. 2655-2677. https://doi.org/10.3390/f6082655

FAO. (2005). Global forest resources assessment update 2005.

Gebreegziabher, Z., \& Mekonnen, A. (2010). Household Tree Planting in Tigrai, Northern Ethiopia. 2473(432).

Gessesse, B., Bewket, W., \& Bräuning, A. (2016). Determinants of farmers' tree-planting investment decisions as a degraded landscape management strategy in the central highlands of Ethiopia. Solid Earth, 7, 639-650. https://doi.org/10.5194/se-7-639-2016

Gordon, J. ., Hawthorne, W., Sandoval, G., \& Barrance, A. . (2003). Trees and farming in the dry zone of southern Honduras II: the potential for tree diversity conservation. Agroforestry Systems, 59, 107-117.

Hedberg, I., \& Sue, E. (1989). Flora of ethiopia Pittosporaceae to Araliaceae (Vol. 3). The National Herbarium, BiologyDepartment, Science Faculty, Addis Ababa University, Ethiopia, and The Department ofSystematic Botany, Uppsala University, Sweden.

Lemage, B., \& Legesse, A. (2018). Management and socioeconomic determinants of woody species diversity in parkland agroforestry in. Biodiversity International Journal, 2(5), 456-462. https://doi.org/10.15406/bij.2018.02.00100

Mekonnen, A., \& Damte, A. (2011). Private Trees as Household Assets and Determinants of Tree-Growing Behavior in Rural Ethiopia. Environment for Development, (December), Efd DP 11-14.

Nair, P. K. R. (1993). An Introduction to Agroforestry. Klgwer Academic Publishers.

Nikiema, A., van der Maesen, L. J. G., Hall, J. B., \& Baas, P. (2005). Agroforestry Parkland Species Diversity:Uses and Management in Semi-Arid West Africa, West, Burkina Faso. Wageningen University.

Oeba, V. O., Otor, S. C. J., Kung, J. B., \& Muchiri, M. N. (2012). Modelling Determinants of Tree Planting and Retention on Farm for Improvement of Forest Cover in Central Kenya. International Scholarly Research Network, 2012, 14. https://doi.org/10.5402/2012/867249

Scherr, S. J., Roger, J. H., \& Oduol, P. A. (1990). Surveying farmers 'agroforestry plots : experiences in evaluating alley-cropping and tree border technologies in Western Kenya. 141-173.

Shete, M. B., \& Fred, M. (2010). Socioeconomic factors determining household level tree species abundance and composition in Gondar district, Ethiopia. the Norweigian University of Life science.

WDOARD. (2011). Wemberma district Office of agricultural and rural development profile document: Unpuplished document.

Yamane, T. (1967). Yamane (2nd Edditi). New York: Horper and Row.

Zeleke, E. A. (2009). Smallholder Farmers' Decision Making in Farm Tree Growing in the Highlands of Ethiopia. 
Oregon State University.

Table 1: Multiple regression results of the number of trees grown per household with socioeconomic Variables in the study site

\begin{tabular}{lll}
\hline Variable & Dafni-shambla & Kentefin \\
\hline (Constant) & -250.76 & -65.56 \\
Gender of HH head & 52.69 & 56.01 \\
Age of HH head & 0.65 & $-3.52^{* *}$ \\
Farming experience & -0.31 & $6.63 * * *$ \\
Marital status & 24.85 & 56.59 \\
Educational status & -10.73 & -2.82 \\
Family size & -18.12 & -14.54 \\
Occupation & 44.28 & -24.81 \\
Wealth & $118.13^{* * *}$ & $29.56^{*}$ \\
Landholding size & $27.56^{* * *}$ & 7.72 \\
\hline R square & 0.719 & 0.600 \\
Adjusted R square & 0.651 & 0.502 \\
\hline Note: Figures in parenthesis are corresponding coefficients for the $t$ value and the marks indicates their level of \\
significance where $*=p<0.1, * * p<0.05$ and $* * *=p<0.01$
\end{tabular}

